\title{
Growth and Reproductive Phenology of Welwitschia Mirabilis Hook. F.
}

\author{
M. Di Salvatore, A. M. Carafa ${ }^{*}$ and G. Carratù
}

Dipartimento di Agraria Università degli Studi di Napoli “Federico II" Facoltà di Agraria, 80055 Portici, Italy

\begin{abstract}
Reproductive phenology, reproductive traits and the pre emergent reproductive success (PERS) of Welwitschia mirabilis were studied in plants growing in the Botanical Garden of Portici. The leaves grow throughout the year and growth is positively correlated to temperature and day length; at flowering, the growth rate slows down. The plants have a reproductive cycle lasting 9-10 months; male plants form more branches and strobili than females, female strobili are larger than male ones. Both male and female plants produce cones that differ in the color of the covering bracts. Plants produce a lot of seeds, but most of them are empty; therefore the seed/ovule ratio is low. Filled and empty seeds are morphologically similar; filled seeds have high vitality that is maintained for several years. As probable causes of the low seed/ovule ratio, both pollination and embryo abortion are taken into account; our observations lead us to believe that the embryo abortion hypothesis is more accurate. However, since each plant may produce a discrete number of cones and filled seeds are highly viable, ultimately Welwitschia appears to be a rather efficient plant in terms of pre emergent reproductive success.
\end{abstract}

Keywords: Welwitschia mirabilis, growth pattern, reproductive phenology, reproductive traits, PERS.

\section{INTRODUCTION}

Welwitschia mirabilis Hook. f. is a monotypic species grouped with the genus Ephedra and Gnetum under the plant Division Gnetophyta, a small group of seed plants having intermediate characteristics between Angiosperms and Gymnosperms. The relationship of Gnetophyta with other seed plants has been widely debated in the last century and is still not resolved [1-5], as a matter of fact Welwitschia appears to be a highly isolated member of an ancient developmental series, probably representing a parallel line of evolution in the plant kingdom and ending in a blind alley [6]; recent fossil evidence suggests that Welwitschia-related plants were present during the lower Cretaceous, approximately 112 million years ago [7]. The plant, discovered in 1859 by the Austrian botanist, explorer and doctor Friedrich Welwitsch, is endemic to the Namib, one of the smallest and oldest deserts in the world, stretching $1500 \mathrm{Km}$ along the west coast of south Angola and north Namibia [8,9]. Since its discovery, $W$. mirabilis has been considered a botanical curiosity with paradoxical characteristics [6]. The plant, a dioecious evergreen, consists of a woody, unbranched stem, shaped as an inverted cone ending with a crater-like depression surrounded by a bi-lobed crown of green, photosynthetic tissue. The plant forms only two opposite, persistent, amphistomatic, parallel-veined and ribbon-shaped leaves growing continuously by means of a basal meristem for the lifespan of the plant and die off at their tips. This amazing morphology arises because, just after the formation of the first couple of leaves, the terminal bud dies [10] and the meristematic activity is transferred to the periphery of the crown and the base of the leaves. The plant has morphological and

\footnotetext{
*Address correspondence to this author at the Dipartimento di Agraria Università degli Studi di Napoli "Federico II" Facoltà di Agraria, 80055 Portici, Italy; Tel: 081-2539386; Email: carafa@unina.it
}

physiological characteristics which are not normally associated with a desert plant: it has non-succulent leaves with immense surface areas, and uses primarily $\mathrm{C} 3$ photosynthesis $[11,12]$, but at the same time also uses CAM-type metabolism $[13,14]$. W. mirabilis grows in geographically isolated populations formed by a few to more than 1000 specimens; the plants are in cohorts, constituted by very old individuals, apparently of a similar age [15], and it is thought that the older specimens may be more than 1500 years old [16]. Beyond the intrinsic value as an endemic species and the speculative interest in the scientific community, Welwitschia is of considerable importance to the local ecosystem because it provides refuge, shade, food, and water to many species of animals that inhabit the Namib [15].

$W$. mirabilis is not regarded as an endangered species because in its natural habitat there are thousands of plants, however this is due to the exceptional long life of the plant rather than due to growth of new seedlings. According to IUCN Red list criteria $W$. mirabilis should be rated as Near Threatened (NT) owing to its slow growth rate and, above all, its worrying low recruitment which could make Welwitschia survival problematic in the wild. Climate change, brought about by anthropogenic carbon emissions, is also likely to pose an additional threat to species with limited distribution and poor regeneration, such as W. mirabilis [17]. Although habitat fragmentation, overgrazing by animals and indiscriminate collection of wild plants by people appear to be the more immediate causes, the fundamental reason for the loss of a species resides in the failure of reproductive processes [18]. Thus, the knowledge of plant reproductive biology is of immense importance for biodiversity conservation, and any conservation approach has to be based on an in-depth study of the reproductive characteristics of plants. During the past century numerous papers have been written about the morphology, anatomy, development, ecophysiol- 
ogy and distribution of W. mirabilis [19] (and references therein), and the anatomy of reproductive organs of this plant has been investigated in detail [20-29]; nevertheless some aspects of the reproductive biology of $W$. mirabilis are still inadequately understood. The aim of this study is to improve our knowledge about growth, reproductive phenology (timing, development and number of reproductive structures) and the reproductive efficiency (PERS and seed quality) of $\mathrm{Wel}$ witschia mirabilis plants growing in the Botanical Gardens of Portici for its better cultivation and conservation.

\section{MATERIALS AND METHODS}

Phenological observations and measurement were carried out on plants of Welwitschia mirabilis growing in the volcanic Vesuvian soil of the succulent's greenhouse of the Botanical Garden at Portici (Naples). The greenhouse is equipped with an automatic heating system which becomes operative when temperature drops below $13^{\circ} \mathrm{C}$. The mean annual minimum and the mean annual maximum temperature we recorded in the greenhouse was $15 \pm 2,5^{\circ} \mathrm{C}$ and $36,6 \pm 4^{\circ} \mathrm{C}$ respectively.

The oldest specimens are two male and two female plants, forty years old, all grown from seeds probably coming from Angola; in 1986 female plants started to produce seeds. At present in the greenhouse there are 16 mature plants from twenty to forty years old; ten are producing female cones and six male cones. In the immediate vicinity of two female plants, 12 small seedlings, between one to seven years old, are growing; they originate from the germination of seeds fallen from the mother plant and left on the surrounding ground by the gardeners. Of these plants two have produced a reproductive shoot with 1 male cone (2011).

\section{Growth Analysis}

Leaves of the four bigger plants, two male and two female, were marked where the leaf emerges from the stem, and growth of the leaf was indicated by the distance of this mark from the edge of the stem. This distance was measured monthly over a period of three years.

\section{Reproductive Characteristics (Secondary Sexual Traits)}

The number of fertile branches (reproductive shoots) per plant, as well as the number of male and female cones per branch and per plant was recorded in all the sixteen plants, and recordings were repeated over a period of three years. The size of male and female cones was measured with a digital calliper on 50 cones for each sex randomly chosen; flowers were counted within the same cones. Male and female flowers were observed and measured by means of a Wild Heerbrugg stereomicroscope. Measurements of pollen grains were recorded by an ocular micrometer fitted to the eyepiece of a Leitz orthoplan microscope.

\section{Reproductive Efficiency}

Since Welwitschia produces only a single ovule/flower, the seed/ovule ratio constitutes a direct measure of pre emergent reproductive success (PERS), i.e. the percentage of ovules that develop into seeds. Mature female cones were harvested in December, just before the dispersion of seeds, and 50 randomly chosen cones were measured; within each strobilus, the filled seeds were counted as well as the empty ones; non-fully-developed seeds of the distal (non productive) zones were discarded; the $\mathrm{S} / \mathrm{O}$ ratio was calculated as $\mathrm{n}$ filled seeds/ ( $\mathrm{n}$ filled seeds $+\mathrm{n}$ empty seeds) according to Berg [30].

Seed quality was evaluated for morphological characteristics such as size and weight, and for viability. Seed length, width and thickness of 100 randomly chosen seeds were measured with a digital calliper; the weight of 100 randomly chosen seeds from either reddish or green cones was measured with an analytical balance $(0.0001 \mathrm{~g}$ Mettler Toledo Inc. Switzerland)

Cone sampling and seed production were repeated for 3 years.

Seeds were stored in desiccators placed in a refrigerator at $4^{\circ} \mathrm{C}$.

Seed viability was determined, according to International Seed Testing Association prescriptions [31] using the triphenyltetrazolium chloride method that is based on the reduction of tetrazolium salts to red colored triphenylformazan in viable tissues. Winged perianths were removed from dispersion units and seeds, after $24 \mathrm{~h}$ of imbibition in water at room temperature, were immersed in a tetrazolium staining solution ( $1 \%$ aqueous solution of 2,3,5-triphenyl tetrazolium chloride) for $48 \mathrm{~h}$ at $25^{\circ} \mathrm{C}$ in the dark; red embryos were counted as alive.

\section{Data Analysis}

Statistical analysis was performed using SPSS 13.0 and Sigma Plot software; all data were subjected to one-way Anova to examine differences in means; differences between means were evaluated for significance by using StudentNewman-Keuls test.

The relationship between monthly growth of leaves and day length and temperatures recorded in the greenhouse as well as strobilus growth and seed number were tested using the Pearson coefficient.

The micrographs were created with a JVC digital camera 3.3 Mpx.

\section{RESULTS}

\section{Leaf Growth}

Average annual growth was $38,15 \pm 1,8 \mathrm{~cm}$ and $40,73 \pm$ $1,77 \mathrm{~cm}$ for male and female plants respectively; the leaves grew throughout the year but the growth rate varied seasonally: lower in the colder months, higher in the warmer months; the leaf growth rate in male and female plants was similar in all months except for May, June and July when the leaves of female plants grew more than the leaves of male plants (Fig. 1). At full bloom, the growth rate slows down in both sexes; in male plants the slowdown ended in August, in female plants it lasted until September. The leaf growth was significantly correlated to temperature recorded in the greenhouse and, of course, to day length during a solar year (Table 1). The parts of leaf newly formed, light green in color, were easily distinguished from the glaucous green oldest parts; simultaneously with basal growth the distal part of the leaves withered so that the vital part in the larger 
specimens was not longer than $100-140 \mathrm{~cm}$. Leaves were longitudinally splitted up to meristematic groove from which they arise, so, just as it does in the wild, it seemed that plants had more than two leaves.

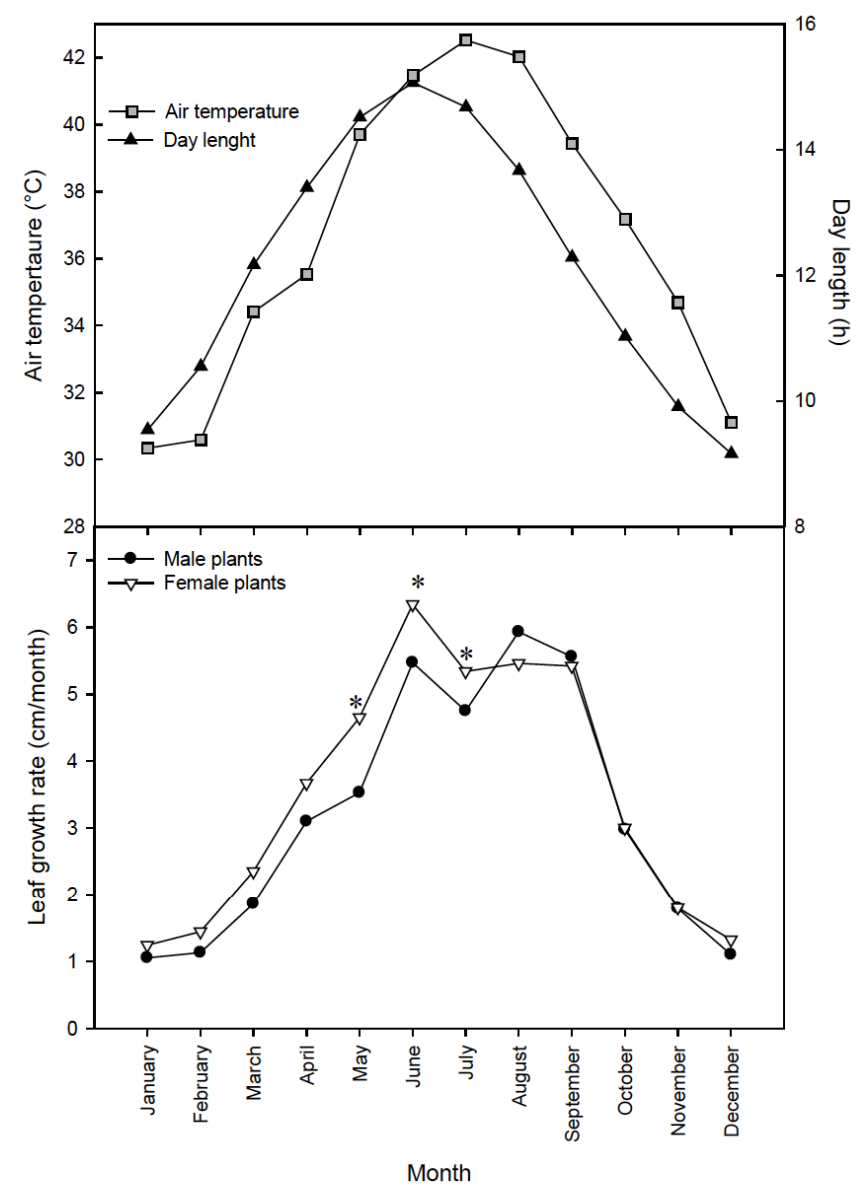

Fig. (1). Leaf growth rate of Welwitschia male and female plants during the year compared to air temperature in the greenhouse and day length. Each value of growth rate represents the mean of three replicas. *indicate significant differences between male and female plants; $(\mathrm{P} \leq 0,05)$.

Table 1. Correlation Between Leaf Growth, Air Temperature and Day Length

\begin{tabular}{|c|c|c|c|}
\hline & Day length & Female plant & Male plant \\
\hline \hline Air temperature & 0,755 & 0,744 & 0,772 \\
\hline Day length & & 0,798 & 0,772 \\
\hline
\end{tabular}

Pearson's correlation coefficient $\leq 0,05$

\section{Reproductive Phenology}

W. mirabilis has a 9-10 month reproductive cycle, from bud initiation on the crown until seed maturation and dispersal (Table 2). In both sexes, buds which would produce reproductive branches became clearly visible in March. Buds were formed, without any particular order, in the outer part of the crown, rarely they were developed on the tissues of crown below the groove from which the leaves were grow- ing, in which case they did not ripen. Reproductive branches lengthened and dichasially branched during the months of April, May and June. In May, micro- and megasporangiate strobili became clearly visible on the branches at the nodes or in terminal position. Flowering started from mid-June (emergence of the first male flowers), and lasted for a period of 8-9 weeks; male cones produced flowers earlier (about 7 10 days) than females. Both microsporangia and ovules matured acropetally. During the progressive maturation of the flowers, strobili were lengthening.

Seed ripening occurred from July to late November, and strobili lengthened during that time.

In the final stages of ripening, the strobili gradually dried, and the color of the covering bracts turned from green to brown. Then, ripe seeds with their covering bracts broke away from the cone axis and fell on the surrounding ground; sometimes in the terminal part of the strobili there were seeds that were still empty. Finally, reproductive branches broke off the crown, leaving a hollow as a trace.

\section{Reproductive Characteristics}

Fertile branch number per plant varied from year to year, but male plants formed more branches than females on average. The number of strobili produced per branch varied widely but male plants produced a number of cones much larger than those produced by female plants; regarding cone size, female strobili were longer and wider than male strobili (Table 3). The basic architecture of both male and female cones was similar: decussate and imbricated covering bracts were positioned along the axis of the strobilus; reproductive units (flowers) were in the axil of bracts, on a short axis. We have called "flowers" the reproductive structures of Welwitschia because synangia and ovules are enclosed by perianth-like elements $[32,33]$, not to imply phylogenetic homology with flowers of angiosperms that at the moment has not been established [34]. Cones produced by microsporangiate plants were reddish or green owing to different color of outer margin of covering bracts (Fig. 2); in fact, in the first case the margin was red, in the second, light green; reddish strobili were smaller, flowered earlier and produced fewer flowers than green strobili (Table 3).

At anthesis, synangia and the discoid apex of micropyle, covered with a copious translucid secretion, protruded from covering bracts. Sticky masses of pollen were released by the dehisced microsporangia and fell on the underlying leaves or, because of curving synangial stalks, in the secretion of micropylar disc (Fig. 2).

Pollen produced by either reddish or green cones was similar in shape and size. Pollen viability, as assessed by "in vitro" germination tests (data not shown), was approximately $70-80 \%$.

In female plants, megasporangiate strobili were brick red or dark green because the outer margin of covering bracts were dull red or anthracite black (Fig. 2). However, size, number of flowers and ripening time were similar. In the female, flower ovules became receptive when, at the top of micropylar tubes that protruded from covering bracts, the sweet micropylar drop appeared. 
Table 2. Chronology of Phenological Events

\begin{tabular}{|c|c|c|c|c|c|c|c|c|c|c|c|c|}
\hline Appearance of reproductive & & & $\mathrm{x}$ & $\mathrm{x}$ & & & & & & & & \\
\hline Reproductive branches & & & & & \multirow{2}{*}{$\mathrm{x}$} & \multirow{2}{*}{$\mathrm{x}$} & & & & & & \\
\hline growth & & & & $x$ & & & & & & & & \\
\hline Flowering period & & & & & & $\mathrm{x}$ & $\mathrm{x}$ & $\mathrm{x}$ & & & & \\
\hline Seed ripening period & & & & & & & $\mathrm{x}$ & $\mathrm{x}$ & $\mathrm{x}$ & $\mathrm{x}$ & $\mathrm{x}$ & \\
\hline Seed dispersal period & & & & & & & & & & & $\mathrm{x}$ & $\mathrm{x}$ \\
\hline
\end{tabular}

Table 3. Reproductive Characteristics of Male and Female Plants

\begin{tabular}{|c|c|c|c|c|}
\hline & \multicolumn{2}{|c|}{$\hat{\jmath}$} & \multicolumn{2}{|c|}{ q } \\
\hline & \multicolumn{2}{|c|}{ Mean \pm SD } & \multicolumn{2}{|c|}{ Mean \pm SD } \\
\hline branches number/plant & \multicolumn{2}{|c|}{$15,72 \mathrm{a}$} & \multicolumn{2}{|c|}{$8,80 \mathrm{~b}$} \\
\hline strobili number/branch & \multicolumn{2}{|c|}{$35,40 \mathrm{a}$} & \multicolumn{2}{|c|}{$6,80 \mathrm{~b}$} \\
\hline strobili number/plant & \multicolumn{2}{|c|}{$511,45 \mathrm{a}$} & \multicolumn{2}{|c|}{$53,4 \mathrm{~b}$} \\
\hline strobili length $(\mathrm{cm})$ & $\underline{\text { reddish }}$ & green & $\underline{\text { red brick }}$ & dark green \\
\hline (late July) & $2,7 \mathrm{~b}$ & $4,1 \mathrm{a}$ & $4,92 \mathrm{a}$ & $4,5 \mathrm{a}$ \\
\hline strobili width $(\mathrm{cm})$ & $0,46 \mathrm{a}$ & $0,68 \mathrm{~b}$ & $1,15 \mathrm{a}$ & $1,17 \mathrm{a}$ \\
\hline flowers number/strobilus & $69,5 \mathrm{~b}$ & $101 \mathrm{a}$ & $95,3 \mathrm{a}$ & $96,28 \mathrm{a}$ \\
\hline \multirow{2}{*}{ pollen size $(\mu \mathrm{m})$} & $\lambda 50,3 \mathrm{a}$ & $\lambda 51,9 \mathrm{a}$ & & \\
\hline & w $27,8 \mathrm{a}$ & w $29,2 \mathrm{a}$ & & \\
\hline \multirow{2}{*}{ female flowers size (mm) } & & & $\lambda 19,7 \mathrm{a}$ & $\lambda 17 \mathrm{a}$ \\
\hline & & & w 26,2 a & w $22 \mathrm{a}$ \\
\hline
\end{tabular}

Different letters in the same row indicate significant differences between means. Student Newman- Keuls test $(\mathrm{P} \leq 0,05)$.

\section{Reproductive Efficiency Assessment}

At maturity, ripe female strobili contained a lot of seeds, but most of them were empty; on average, the Seed/Ovule ratio was low (Table 4). During seed ripening, strobili grew so much as to double their length when compared to female strobili length at flowering; the correlation coefficient between strobili length and seed number showed that length was independent from seed number, both filled and empty (data non shown). Seed units or dispersion units were released by cones, and in them was the true seed with its seminal integument wrapped by the winged outer covering bracts [16]; in this paper we have considered these seed units. Filled and empty seeds were similar in size, but the former were easily distinguished from the latter because they were firm to the touch and were significantly heavier (Table 5). The empty seeds were light because all the tissues, except for the integument and winged outer covering, were degen- erate. Viability tests showed that filled seeds had a high vitality, viable embryos were deep red (Fig. 2), and the nonviable ones were devoid of coloration. Viability of the seeds stored at $4^{\circ} \mathrm{C}$ remained high during the first three years, afterwards decreased with storage time and at the same time the quota of partially or non viable seeds increased (Fig. 3).

\section{DISCUSSION}

In the greenhouse, leaves of Welwitschia grow throughout the year. In the wild the growth is about $8-13 \mathrm{~cm} /$ year $[3,6]$ and it is affected by rainfall [35]. In the greenhouse we recorded decidedly higher growth per year, correlated to temperature and day length. The moisture content of substrate does not constitute a limiting factor because plants are watered when necessary. Our results coincide with the observations of Song [36], van Jaarsveld [37, 38] and Sen- 
ters [39] who have described cultivation of Welwitschia in the Botanical Gardens of UCLA (California), Kirstenbosh (South Africa) and Washington State University. All the aforementioned authors agreed in considering that, in order for Welwitschia to grow successfully, it is crucial to use very permeable soil, and the Vesuvian soil in the greenhouse, which is very fertile and permeable, has proven to be highly beneficial for the successful cultivation and flowering of our Welwitschia.

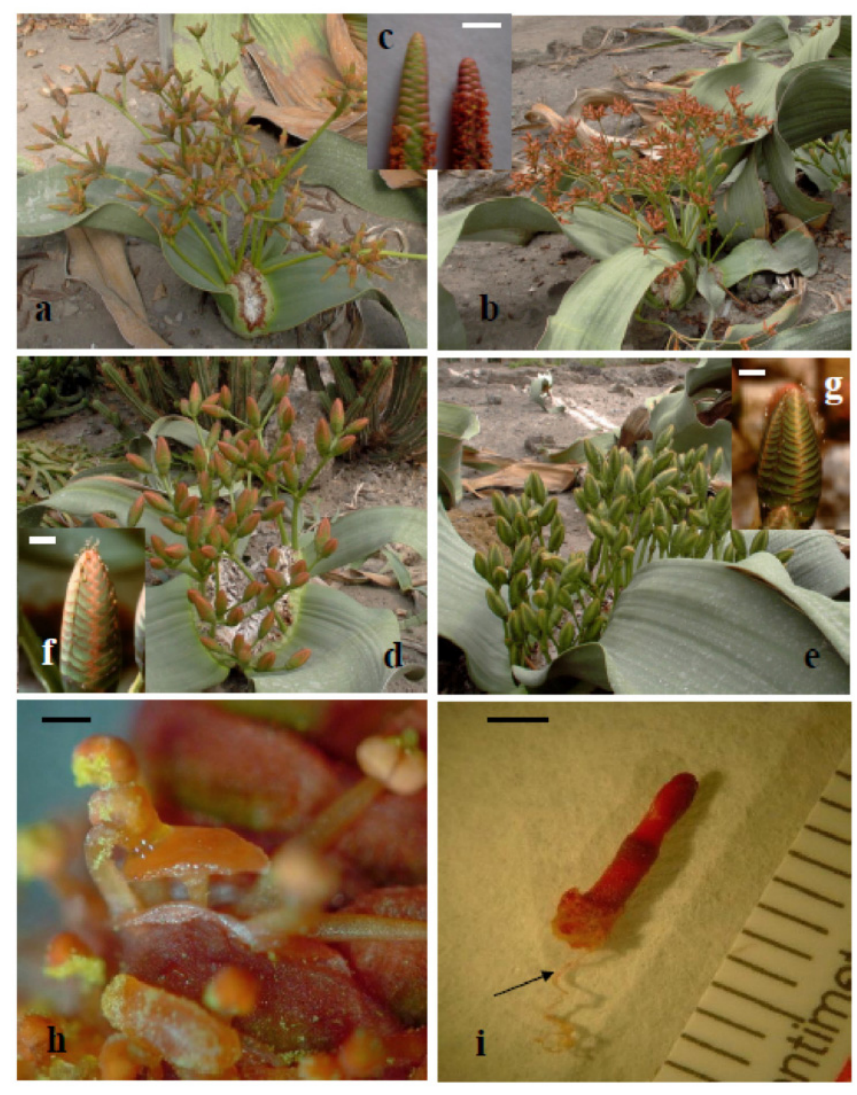

Fig. (2). (a). male plant with green cones. (b). male plants with reddish cones. (c). reddish (right) and green (left) male cones at blooming; scale bar $0,5 \mathrm{~cm}$. (d). female plant with red brick cones. (e). female plants with dark green cones. Female red brick (f) and dark green (g) cones with pollination drops; scale bar $0,5 \mathrm{~cm}$. (h) synangia releasing pollen in the fluid covering the discoid apex of micropyle in the male flower; scale bar $0,5 \mathrm{~mm}$. (i) vital embryo after tetrazolium test showing a long coiled suspensor (arrow); scale bar $2 \mathrm{~mm}$.

Table 4. Characteristics of Female Strobilus

\begin{tabular}{|c|c|c|}
\hline & Mean \pm SD & Range \\
\hline \hline ripe female strobilus size (cm) & \multirow{2}{*}{$10,30 \pm 2,2$} & $5,20-18,5$ \\
\hline (late November) & & \\
\hline seeds number/strobilus & $79,90 \pm 16,5$ & $50-124$ \\
\hline filled seeds/strobilus & $27,70 \pm 12,3$ & $6,00-58$ \\
\hline seed/ovules ratio & $0,30 \pm 0,05$ & $0,21-0,39$ \\
\hline
\end{tabular}

Table 5. Seed Characteristics

\begin{tabular}{|c|c|c|}
\hline & Filled seeds & Empty seeds \\
\hline \hline width $(\mathrm{cm})$ & $3,1 \mathrm{a}$ & $3,2 \mathrm{a}$ \\
\hline length $(\mathrm{cm})$ & $2,6 \mathrm{a}$ & $2,2 \mathrm{a}$ \\
\hline thinckness $(\mathrm{cm})$ & $0,2 \mathrm{a}$ & $0,02 \mathrm{~b}$ \\
\hline weight $(\mathrm{mg})$ & $82,7 \mathrm{a}$ & $26,5 \mathrm{~b}$ \\
\hline
\end{tabular}

Values refer to dispersion units (true seed + winged perianth)

Different letters in the same row indicate significant differences between means. Student Newman- Keuls test $(\mathrm{P} \leq 0,05)$.

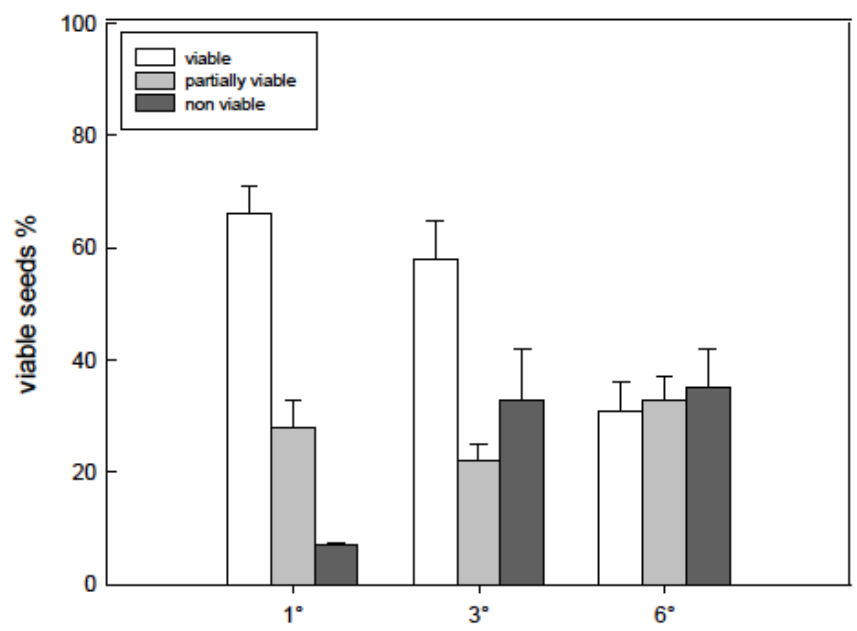

Fig. (3). Viability of Welwitschia mirabilis seeds after one, three and six years of storage at $4^{\circ} \mathrm{C}$. Triphenyltetrazolium chloride method. Three replicas, each of twenty seeds; bars indicate the standard deviation.

In addition, in the greenhouse, as in the wild, the leaves are longitudinally split; we agree with [16] who suggest that the splitting of the leaves is the result of differential pressure caused by unequal growth of the meristematic terminal groove of the stem rather than by wind action because in the greenhouse there is no wind.

The decrease of leaf growth rates at flowering for both male and female plants may be related to the energy costs of reproduction [40, 41]; in fact, leaves of the male plants, which produce more numerous fertile branches and cones than female ones, grow less than the leaves of female plants. In this respect, it is significant that for male plants, the leaf growth rate increases again once the flowering stage is complete; something which does not happen for female plants which are still involved in seed ripening. The differences in the colour of both male and female strobili can be related to genetic variations of $W$. mirabilis [42]. In particular, regarding male cones, our observations are in agreement with Leunberger [43] who, by observations of plants cultivated in the Botanical Garden Berlin- Dahlem, described two subspecies of Welwitschia: W. mirabilis subsp. namibiana, and W.mirabilis subsp. mirabilis on the basis of morphological differences of male strobili. Beyond these morphological differences both types of male cones produce copious pollen that is transported by pollinators to female strobili $[44,45]$. It 
is interesting to note that in the entomophilous pollination of Welwitschia, fructose is the dominant sugar in both the micropylar drop of female flowers [46] and the secretion that wets the micropylar disc of male flowers [47].

Male and female plants of Welwitschia, as is the case for many dioecious seed plants [48-50] show pronounced differences in secondary sexual traits; Welwitschia male plants produce smaller and much more numerous cones than females. The predominance of male cones may be related to the lower energy costs for producing male as compared to ovulate cones $[40,41,49,51]$ and to the necessity of producing greater amounts of pollen in order to increase the chances of successful pollination [48]; vice versa, the production of a smaller number of cones by the female plants can be seen as a strategy carried out by the plant to conserve adequate resources needed for the production of seeds [49, 52].

In plant biology, reproductive success is subdivided into pre emergent and post emergent phases; in seed plants, pre emergent reproductive success (PERS) is measured by the number of ovules that mature into viable seeds released from the maternal parent; post emergent reproductive success includes the stages in the plant life cycle from seed germination to reproductive maturity [53]. In this work we evaluated only the pre emergent reproductive success of Welwitschia: ovulate strobili, as has been observed in the wild [16, 20], produce each year a large number of flowers, sometimes more than 100 per strobilus, nevertheless the average filled seed production observed during the present study was low if compared to mean ovules (flowers) production. Several studies (see [54]) suggest that natural and artificial pollination does not result in $100 \%$ seed set, and that the number of flowers usually exceeds seed set even when all the flowers were pollinated. In the Spermatophytes the main mechanisms responsible for low seed/ ovule ratio are lack of pollination, pollination scarce or with poorly viable pollen [55$60]$, maternal resource limitation [54,60], and embryo abortion $[54,57,61,62]$. While we do not know which of these mechanisms cause the low seed/ovule ratio in Welwitschia, we can make some considerations by taking into account what we have observed: in Welwitschia plants, a large amount of pollen is produced, which is transported by pollinators to the micropylar drop $[44,45]$ where it germinates $[21,46]$, pollen germinability, as assessed by "in vitro" germination tests, was high (data not shown), so it seems more likely that the hypotheses proposing a lack of pollination or pollination with poorly viable pollen should be rejected, while the hypothesis of low pollination remains valid. Some other evidence leads us to consider as likely the embryo abortion hypothesis: a) the lengthening of cones during the ripening of the seeds undoubtedly is due to growth of the ovule; in fact, although in Gymnospermae the megagametophyte grows and accumulates nutrients before fertilization [63], we know that in Welwitschia the calazal part of megagametophyte increases much once fertilization occurred for further accumulation of reserve materials [64]; b) both filled and empty seeds have similar size, however Owens et al. [56] for Thuja plicata and Oritz et al. [59] for Juniperus oxycedrus have shown that filled and empty seeds are indistinguishable when abortion occurs after fertilization, c) in Welwitschia what distinguishes empty seeds is degenera- tion of all the internal tissues of megagametophyte; similar observations have been made by Sarvas [61] in Pinus silvestris and Owens et al. [57] in Pseudotsuga menziesii who observed that embryo death causes rapid degeneration of megagametophyte while accumulated nutrients are transferred elsewhere [65]. High seed abortion rates occur frequently in outcrossing, long-lived species because investment in the maturing embryos may be very large [53, $66]$; several studies have shown that causes of seed abortion could be the competition for limited maternal resource among ovules [53, 54, 67, 68], genetic factors [53, 69], expressed in developing embryos or in the maternal plants [62], or parasite attacks $[57,70]$. This last point could have some significance, in fact, if the seeds of Welwitschia are heavily infected by the fungus Aspergillus niger [8, 15], hyphae and conidiophhores are mostly found on the outer seed covering, but when fungus spores are found embedded in the pollination drop at the tip of micropyle, the fungus can reach the gametophyte and degrade it [71].

Regeneration from seed is an essential feature of the life cycle of most plants, and in Welwitschia regeneration can be achieved only through seeds; the seeds of Welwitschia are hortodox [72] and they have a high viability that is retained for several years [73]. Filled seed production is low if compared to the total number of produced seeds, however, the fact that each of the plants (larger specimens) can produce even more than 100 strobili means that sufficient seeds might be produced that would permit the establishment of seedlings under favorable conditions. From this point of view, then, Welwitschia looks like a rather efficient plant in terms of reproductive success. On the other hand, the natural recruitment we observed in the greenhouse shows that the plant can reproduce quite easily as long as the external conditions are suitable for seed germination and seedling growth. We are currently carrying out more detailed investigations regarding this, and the results will be the subject of a forthcoming work.

\section{CONFLICT OF INTEREST}

The author(s) confirm that this article content has no conflicts of interest.

\section{ACKNOWLEDGEMENT}

The authors are indebted to Prof. Paolo Pizzolongo for his excellent personal support during the study period. We wish to thank Mrs. Pina Chianese for technical assistance and the Botanical Garden staff for their expertise in the cultivation of Welwitschia. We wish to thank again Dr. Chiara Cirillo and Dr. Boris Basile for their assistance in the statistical data processing, and Mrs. Dianna Pikens for her critical revision of the language.

\section{REFERENCES}

[1] Doyle JA, Donoghue MJ. Seed plant phylogeny and the origin of angiosperms: an experimental cladistic approach. Bot Rev 1986; 52: $321-431$.

[2] Chaw S, Parkinson CL, Cheng Y, Vicent TM, Palmer JD. Seed plant phylogeny inferred from all three plant genomes: Monophyly of extant gymnosperms and origin of Gnetales from conifers. Proc Natl Acad Sci USA 2000; 97: 4086-91. 
[3] Rydin C, Kallersjo M, Friis EM. Seed plant relationship and the systematic position of Gnetales based on nuclear and chloroplast DNA: conflicting data, Rooting problems, and the monophyly of conifers 2002 .

[4] Frohlich MW, Chase MW. After a dozen years of progress the origin of angiosperms is still a great mystery. Nature 2007; 450: 1184- 9 .

[5] Rudall PJ, Bateman RM. Defining the limits of flowers: the challenge of distinguishing between the evolutionary products of simple versus compound strobili. Philos Trans R Soc Lond B. 2010; 365: 397-09.

[6] Bornman CH. Welwitschia mirabilis: paradox of the Namib Desert. Endeavour 1972; (XXXI) 95-9.

[7] Dilcher DL, Bernardes-De-Oliveira ME, Pons D, Lott TA. Welwitschiaceae from the lower cretaceous of northeaster Brazil. Am J Bot 2005; 92(8): 1294-10.

[8] Rodin RJ. Distribution of Welwitschia mirabilis. Am J Bot 1953; 40: 280-5.

[9] Kers LE. The distribution of Welwitschia mirabilis Hook. f. Svensk Botanisk Tidskrif 1967; 61: 97-125.

[10] Martens P. Welwitschia mirabilis and neoteny. Am J Bot 1977; 64(7): 916-20.

[11] von Willert DJ, Eller BM, Brinckmann E, Baasch R. CO ${ }^{2}$ Gas Exchange and traspiration of Welwitschia mirabilis Hook. F. Central Namib Desert 1982; Oecologia 55: 21-9.

[12] Eller BM, von Willert DJ, Brinckmann E, Baasch R. Ecophysiological studies on Welwitschia mirabilis in the Namib desert. S Afr J Bot 1983; 2: 209-23.

[13] Schulze ED, Ziegler H, Stichler W. Environmental control of crassulacean acid metabolism in Welwitschia mirabilis Hook. Fil in Its Range of Natural Distibution in the Namib Desert. Oecologia 1976; 24: 323-34.

[14] von Willert DJ, Armbruster N, Drees T, Zaborowski M. Welwitschia mirabilis: CAM or not CAM - what is the answer? Funct Plant Biol 2005; 32: 389-95.

[15] Cooper-Driver GA, Wagner C, Kolberg H. Patterns of Aspergillus niger var. phoenicis (Corda) Al-Musallam infection in Namibian population of Welwitschia mirabilis Hook. f. J Arid Environ 2000; 46: 181-98.

[16] Bornman CH, Elsworthy JA, Butler V, Botha CEJ. Welwitschia mirabilis: Observation on general habit, seed, seedling, and leaf characteristics. Madoqua 1972; (II)1: 53-6.

[17] Hawkins B, Sharrock S, Havens K. Plants and climate change: which future? Botanic Gardens Conservation International: Richmond, 2008 .

[18] Moza MK, Bhatnagar AK. Plant reproduction biology studies crucial for conservation. Curr Sci India 2007; 92: 1207.

[19] Henschel JR, Seely MK. Long-term growth of Welwitschia mirabilis, a long lived plant of the Namib Desert (including a bibliography). Plant Ecol 2000; 150: 7-26.

[20] Pearson HHW. Some observations on Welwitschia mirabilis Hooker f. Philos Trans R Soc Lond, ser B 1906; 198: 265-304.

[21] Pearson HHW. Further observations on Welwitschia. Philos Trans Roy Soc B 200: 331-02.

[22] Church AH. On the floral mechanism of Welwitschia mirabilis (Hooker). Philos Trans R Soc B 1914; 205: 115-51.

[23] Rodin RJ. Anatomy of the reproductive bracts in Welwitschia. Am J Bot 1963; 50: 641-8.

[24] Martens P. Les Gnétophytes. Encyclopaedia of Plant Anatomy Gebruder Borntrager, Berlin 1971; 12:2.

[25] Martens PEtudes sur les Gnetales- XV: recherches sur Welwitschia mirabilis- VII: Histologie et Histogenèse de la fleur femelle. La Cellule 1975a; 71: 103-44.

[26] Martens P. Etudes sur les Gnetales- XVI: recherches sur Welwitschia mirabilis- VIII: Histologie et Histogenèse de la fleur male. La Cellule 1975b; 71: 147-56.

[27] Endress PK. Structure and function of female and bisexual organ complexes in Gnetales. Int J Plant Sci 1996; 157(6 Suppl.), S11325

[28] Hufford L. The morphology and evolution of male reproductive structures of Gnetales. Int J Plant Sci 1996; 157(6 Suppl.): S95-12.

[29] Mundry M, Stutzel T. Morphogenesis of the reproductive shoots of Welwitschia mirabilis and Ephedra distachya (Gnetales), and its evolutionary implications. Org Divers Evol 2004; 4: 91-08.
[30] Berg H. Factors influencing seed: ovule ratios and reproductive success in four cleistogamous species: a comparison between two flower types. Plant Biol 2003; 5: 194-202.

[31] ISTA. International Rules for Seed Testing. ISTA: Bassersdorf, Switzerland 2003.

[32] Pearson HHW. Gnetales.; Cambridge University Press: London 1929.

[33] Martens P. Les Gnétophytes. Encyclopaedia of Plant Anatomy Gebruder Borntrager, Berlin 1971; 12:2

[34] Hufford L. The morphology and evolution of male reproductive structures of Gnetales. Int J Plant Sci 1996; 157(6 Suppl.): S95S112.

[35] Henschel JR, Seely MK. Long-term growth of Welwitschia mirabilis, a long lived plant of the Namib Desert (including a bibliography). Plant Ecol 2000; 150: 7-26.

[36] Song LC. Gross morphology of developing male and female strobili of Welwitschia mirabilis Hook f. Cactus Succulent J (U.S.) 1980; 52: 68-73.

[37] van Jaarsveld EJ. The cultivation and care of Welwitschia mirabilis, the extraordinary caudiciform of the Namib Desert. Aloe 1990; 27(3): 69-82

[38] van Jaarsveld EJ. Welwitschia mirabilis in cultivation at Kirstenbosh. Veld Flora 1992; 12: 119-21.

[39] Senters AE. Welwitschia mirabilis cultivation. AERGC Newsletter 1997; 10: 5-7.

[40] Agren J. Sexual differences in biomass and nutrient allocation in the dioecious Rubus chamaemorus. Ecology 1998; 69: 962-73.

[41] Cipollini ML, Whigham DF. Sexual dimorphism and cost of reproduction in the dioecious shrub Lindera benzoin (Lauraceae). Am J Bot 1994; 81(1): 65-75.

[42] Jacobson KM, Lester E. A first assessment of genetic variation in Welwitschia mirabilis Hook . J Hered 2003; 94(3): 212-17.

[43] Leuenberger BE. Welwitschia mirabilis ( Welwitschiaceae), male cone characters and a new subspecies. Willdenovia 2001; 31:35781 .

[44] Carafa AM, Napolitano G, D’Acunzo A. Welwitschia mirabilis Hook.: una strana pianta del deserto della Namibia. Nat Montagna 1989; 36(3-4): 17-20.

[45] Wetschnig W, Depisch B. Pollination biology of Welwitschia mirabilis Hook f. (Welwitsciaceae, Gnetopsida). Phyton 1999; 39(1):167-83.

[46] Carafa AM, Carratù G, Pizzolongo P. Anatomical observations on the nucellar apex of Welwitschia mirabilis and the chemical composition of the micropylar drop. Sexual Plant Reprod 1992; 5: 275 9.

[47] Di Salvatore M, Ferrante P, Carratù G, Carafa AM. L'ovulo sterile e la goccia micropilare nel fiore maschile di Welwitschia mirabilis Hook. Fil. Proceedings $107^{\circ}$ Congresso della Società Botanica Italiana- Benevento 2012; 18-22: 79.

[48] Bawa KS, Opler PA. Dioecism in tropical forest trees. Evolution 1975; 29: 167-79.

[49] Lloyd DG, Webb CJ. Secondary sex characters in seed plants. Bot Rev 1997; 43: 177-16.

[50] Ornduff R. Gender performance in a cultivated cohort of the cycad Zamia integrifolia (Zamiaceae). Am J Bot 1996; 83(8): 1006-15.

[51] Freeman DC, Klikoff LG, Harper KT. Differential resource utilization by the sexes of dioecious plants. Science 1976; 193: 597-99.

[52] Antos JA, Allen GA. Biomass allocation among reproductive structures in the dioecious shrub Cemienia verasiformis - a functional interpretation. J Ecol 1994; 82: 21-9.

[53] Wiens D, Calvin CL, Wilson CA, Davern CI, Frank D, Seavey SR Reproductive success, spontaneous embryo abortion, and genetic load in flowering plants. Oecologia 1987; 71: 501-9.

[54] Stephenson AG. Flower and fruit abortion: proximate causes and ultimate functions. Ann Rev Ecol Syst 1981; 12: 253-79.

[55] Bierzychudek P. Pollinator limitation of plant reproductive effort Am Nat 1981; 117: 838-40.

[56] Owens JN, Colangeli AM, Morris SJ. The effect of self-, cross-, and no pollination on ovule, embryo, seed, and cone development in western red cedar (Thuja plicata). Can J Forest Res 1990; 20: 6675.

[57] Owens JN, Colangeli AM, Morris SJ. Factors affecting seed set in Douglas fir (Pseudotsuga menziesii). Can J Bot 1991; 69: 229-38.

[58] Arista M, Talavera S. Density effect on the fruit-set, seed crop viability and seedling vigour of Abies pinsapo. Ann Bot Lond 1996; 77: 187-92. 
[59] Oritz PL, Arista M, Talavera S. Low reproductive success in two subspecies of Juniperus oxycedrus L. Int J Plant Sci 1998; 159(5): 843-7.

[60] Knight TM, Steets JA, Vamosi JC, et al. Pollen limitation of plant reproduction: pattern and process. Ann Rev Ecol Evol S 2005; 36: 467-97.

[61] Sarvas R. Investigations on the flowering and seed crop of Pinus silvestris. Comm Inst Forest Fenn 1962; 53: 1-198.

[62] Karkkainen K, Savolainen O, Koski V. Why do plants abort so many developing seeds: bad offspring or bad maternal genotypes? Evol Ecol 1999; 13: 305-17.

[63] Singh H. Embryology of gymnosperms. Encyclopedia of Plant Anatomy - Gebruder Borntraeger- Berlin 1978.

[64] Martens P, Waterkeyn L. Etudes sur les Gnetales- XIII: recherches sur Welwitschia mirabilis- V: evolution ovulaire et embryogénese. La Cellule 1973; 70: 165-257.

[65] Vuosku J, Sarjala T, Jokela A, et al. One tissue, two fates: different roles of megagametophyte cells during Scot pine embryogenesis. J Exp Bot 2009; 60(4): 1375-86.

[66] Charlesworth D. Evolution of low female fertility in plants: pollen limitation, resource allocation and genetic load. Trends Ecol Evol 1989; 4: 289-2.
[67] Lee TD, Bazzaz FA. Maternal regulation of fecundity: non random ovule abortion of Cassia fasciculata Michx. Oecologia 1986; 68 : 459-5.

[68] Sun K, Hunt K, Hauser BA. Ovule abortion in Arabidopsis triggered by stress. Plant Physiol 2004; 135: 2358- 7.

[69] Bawa KS, Webb CJ. Flower, fruit and seed abortion in tropical forest trees: implications for the evolution of paternal and maternal reproductive patterns. Am J Bot 1984; 71, 736-51.

[70] Tillman-Sutela E, Kauppi A, Hilli A, Kaitera J. Fungal injury to seed tissues of Norway spruce, Picea abies (L.) Karst. Trees 2004; 18: 151-6.

[71] Whitaker C, Pammenter NW, Berjak P. Infection of the cones and seeds of Welwitschia mirabilis by Aspergillus niger var. phoenicis in the Namib-Naukluft Park. South Afr J Bot 2008; 74: 41-50.

[72] Whitaker C, Berjak P, Kolberg H, Pammenter NW. Responses to various manipulations, and storage potential, of seeds of the unique desert gymnosperm, Welwitschia mirabilis Hook.fil. South Afr J Bot 2004; 70: 621-9.

[73] Berjak P, Pammenter NW. Recent progress towards the understanding of desiccation tolerance. In: Adkins S, Ashmore S, Navie SC (Eds), seeds: biology, development and ecology. CAB International 2007; pp. 17-27.

Received: November 08, 2013

Revised: November 25, 2013

Accepted: November 28, 2013

(C) Di Salvatore et al:; Licensee Bentham Open.

This is an open access article licensed under the terms of the Creative Commons Attribution Non-Commercial License (http://creativecommons.org/licenses/by-nc/3.0/) which permits unrestricted, non-commercial use, distribution and reproduction in any medium, provided the work is properly cited. 